"Енергетика і автоматика", №1, 2020 р.

UDC 514.18

DOI 10.31548/energiya2020.01.101

\title{
MODELING OF THE PARTICLE MOTION TRAJECTORY ON THE SURFACE IN ITS INTERNAL COORDINATES
}

\section{A. V. Nesvidomin, Candidate of Technical Sciences, Senior Lecturer \\ National University of Life and Environmental Sciences of Ukraine}

E-mail: a.nesvidomin@gmail.com

\begin{abstract}
In many technological processes of agricultural production there is an interaction of the moving particle with the rough surface. Determination of the laws of motion of a particle on the plane of an arbitrary position in three-dimensional space allows to perform the calculation of structural-kinematic parameters of the working bodies.

Computer simulation of particle motion allows to replace cumbersome analytical transformations and provide a dialog mode for carrying out the necessary computational experiments to analyze the motion of a particle under different initial conditions of its throwing on any rough surface, which is in a certain way located in space.

The purpose of the study is to model the trajectory of motion of a particle on a surface in its internal coordinates.

The general algorithm for modeling the motion of a particle on an arbitrary surface is based on its internal geometry, which is expressed by the coefficients of quadratic shapes, curved lines on the surface, and accompanying triangles.

The paper describes the formation of a particle trajectory on a surface in its internal coordinates.

Various approaches to the formation of the trajectory of the particle $\boldsymbol{r}_{\text {in }}$ the inner

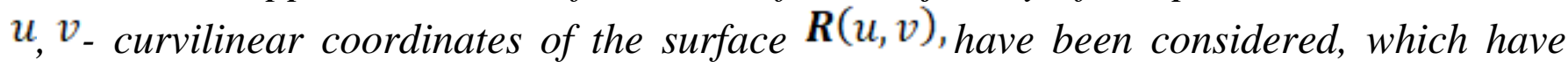
their peculiarities by controlling its independent parameter: time $t$, position $u, v$, direction of motion $\alpha$, length $s$.

The given equations of the trajectories $\boldsymbol{r}(t), \boldsymbol{r}(u), \boldsymbol{r}(v), \boldsymbol{r}(\alpha)$ and $\boldsymbol{r}(s)$ in the inner $u, v$ - coordinates of the surface $\boldsymbol{R}(u, v)$ are necessary and sufficient to determine in the general form their trajectory-kinematic characteristics, respectively, in the function of independent parameters $t, u, v, \alpha$ and $s$.
\end{abstract}

Key words: material point, trajectory of motion, internal coordinates

Topicality. The "rough work surface - moving particle" interaction takes place in many technological processes of agricultural production. production. A characteristic example of such interaction is the movement of granules in mineral fertilizer dispensers [1]. 
"Енергетика і автоматика", №1, 2020 р.

Establishing patterns of motion of a particle (as a material point) on a rough surface allows to calculate the structural-kinematic parameters of the working bodies.

Analysis of recent research and publications. The complexity of the analytical description of the motion of a particle on a rough surface leads to the use of simple in shape surfaces and their partial positions in space. To simplify the analytical transformations of the derivation of the law of motion of a particle on a rough surface in the form of a system of differential equations of the 2 nd order and their solution, each scientist individually adopted one or another system of reference - Cartesian rectangular, cylindrical, spherical, etc.

Computer technologies make it possible to efficiently solve certain stages of motion modeling of a particle on a rough surface, for example, to approximate the system of differential equations of any complexity, to graphically refine the trajectory-kinematic characteristics, etc. [2].

The development of computer-based symbolic computing technologies completely eliminates the time-consuming analytical transformations for shaping the law of motion of a particle on a rough surface, leaving only an interactive computational experiment [3].

The purpose of the study is to model the trajectory of motion of a particle on a surface in its internal coordinates.

Materials and methods of research. The general algorithm for modeling the motion of a particle on an arbitrary surface is based on its internal geometry, which is expressed by the coefficients of quadratic shapes, curved lines on the surface, and accompanying triangles.

Results of the studies and their discussion. We show the formation of the trajectory of a particle on a surface in its internal coordinates.

An arbitrary initial surface $\boldsymbol{R}(u, v)$ on which a particle moves will always be given in vector-parametric form:

$$
\boldsymbol{R}(u, v)=\boldsymbol{R}[x(u, v), y(u, v), z(u, v)],
$$

where $u, v$ - internal coordinates (scalar arguments) of the surface $\boldsymbol{R}(u, v)$. 
"Енергетика і автоматика", №1, 2020 р.

Then any curvilinear trajectory $\boldsymbol{r}$ of a particle on the surface $\boldsymbol{R}(u, v)$ an be expressed by a certain dependence $f(u, v)=0$, which binds $u$ and $v$-curvilinear internal coordinates of the surface $\boldsymbol{R}(u, v)$ as a function of some independent parameter. For example, from time $\boldsymbol{t}$ the trajectory of a particle will be represented by the expressions:

$$
u=u(t), v=v(t) .
$$

Substituting them to equation (1) of the surface $\boldsymbol{R}(u, v)$ will determine the radius vector $\boldsymbol{r}(t)$ of the position of the particle (its trajectory) in the Cartesian $O x y z$ coordinate system::

$$
\boldsymbol{r}(t)=\boldsymbol{R}[u(t), v(t)]=\boldsymbol{r}[x(u(t), v(t)), y(u(t), v(t)), z(u(t), v(t))],
$$

where $t \in\left[t_{0}, t_{N}\right]$ - the start and end values of the independent parameter $t$.

The differentiation of the functions $x(t), y(t)$ and $z(t)$ provides the continuity and smoothness of the trajectory $\boldsymbol{r}(t)$ of the particle, which allows to determine the necessary geometric and kinematic properties of its motion, in particular:

the vector of tangent $\boldsymbol{\tau}(t)$, coinciding with the velocity vector $\boldsymbol{V}(t)$ :

$$
\boldsymbol{\tau}(t) \equiv \boldsymbol{V}(t)=\frac{d}{d t} \boldsymbol{r}(t)=\boldsymbol{\tau}\left[\frac{d}{d t} x(t), \frac{d}{d t} y(t), \frac{d}{d t} z(t)\right] ;
$$

vector of acceleration $\boldsymbol{w}(t)$ :

$$
\boldsymbol{w}(t)=\frac{d}{d t} \boldsymbol{\tau}(t)=\frac{d}{d t}\left(\frac{d}{d t} \boldsymbol{r}(t)\right)=\boldsymbol{w}\left[\frac{d^{2}}{d t^{2}} x(t), \frac{d^{2}}{d t^{2}} y(t), \frac{d^{2}}{d t^{2}} z(t)\right] ;
$$

curvature $k(t)$ :

$$
k(t)=\frac{|\boldsymbol{\tau}(t) \times \boldsymbol{w}(t)|}{|\boldsymbol{\tau}(t)|^{3}} ;
$$

length $s(t)$ of the arc of the trajectory $r(t)$ (traveled by a particle):

$$
s(t)=\int|\boldsymbol{\tau}(t)|=\int d s d t
$$

where $d s$ - differential arc:

$$
d s=\sqrt{\left(\frac{d}{d t} x(t)\right)^{2}+\left(\frac{d}{d t} y(t)\right)^{2}+\left(\frac{d}{d t} z(t)\right)^{2}} d t,
$$

and other vector and numerical dependencies in the function of the variable parameter $t$. 
The acceleration vector $\boldsymbol{W}(t) \equiv \boldsymbol{w}(t)$ of the particle, as a derivative of velocity vector $\boldsymbol{V}(t)$ over time $t$, is written in the following expanded form:

$$
\begin{gathered}
\boldsymbol{W}(t)=\frac{d}{d t} \boldsymbol{V}(t)=\boldsymbol{V}\left[\frac{d^{2}}{d t^{2}}(t), \frac{d^{2}}{d t^{2}} y(t), \frac{d^{2}}{d t^{2}} z(t)\right]= \\
\frac{d}{d t .}(V(t) \boldsymbol{\tau}(s))=\frac{d}{d t .} V(t) \boldsymbol{\tau}(s)+V(t)^{2} k(t) \boldsymbol{n}(s)=\boldsymbol{W}_{\tau}+\boldsymbol{W}_{n},
\end{gathered}
$$

where $\boldsymbol{W}_{\tau}$ i $\boldsymbol{W}_{n}$ - vectors of tangential and normal acceleration.

If, for the independent parameter $t$ we take the $u$ - curvilinear coordinate $(t \equiv u)$, then the trajectory of the particle in the inner $u, v$-coordinates of the surface $\boldsymbol{R}(u, v)$ will be expressed by several other expressions:

$$
u=u, v=v(u),
$$

or in the coordinate system Oxyz:

$$
\boldsymbol{r}(u)=\boldsymbol{R}[u, v(u)]=\boldsymbol{r}[x(u, v(u)), y(u, v(u)), z(u, v(u))] .
$$

Parameter $t$ can also be taken as a $v$-curvilinear coordinate $(t \equiv v)$, where the particle trajectory in the inner $u, v$-coordinates of the surface $\boldsymbol{R}(u, v)$ and in the Cartesian coordinate system $O x y z$ will have, respectively:

$$
u=u(v), v=v,
$$

and

$$
\boldsymbol{r}(v)=\boldsymbol{R}[u(v), v]=\boldsymbol{r}[x(u(v), v), y(u(v), v), z(u(v), v)] .
$$

For the surface $\boldsymbol{R}(u, v)$ with orthogonal $u, v$-coordinate lines (figure), the ratio of their differentials is:

$$
\frac{\sqrt{G} d v}{\sqrt{E} d u}=\operatorname{ctg}(\alpha(u))
$$

where $E, G$ - coefficients of the 1st quadratic form, which are calculated through partial derivatives of surfaces $\boldsymbol{R}(u, v)$ :

$$
\begin{aligned}
& E=\left(\boldsymbol{R}_{u}^{\prime}\right)^{2}=\left(\frac{\partial}{\partial u} x(u, v)\right)^{2}+\left(\frac{\partial}{\partial u} y(u, v)\right)^{2}+\left(\frac{\partial}{\partial u} z(u, v)\right)^{2}, \\
& G=\left(\boldsymbol{R}_{v}^{\prime}\right)^{2}=\left(\frac{\partial}{\partial v} x(u, v)\right)^{2}+\left(\frac{\partial}{\partial v} y(u, v)\right)^{2}+\left(\frac{\partial}{\partial v} z(u, v)\right)^{2} .
\end{aligned}
$$

With the help of dependence (14) it is possible to form the trajectory $r(\alpha(u))$ of the particle on the surface $R(u, v)$ in the function of an independent variable $\alpha(u)$ - the angle 
between the tangent $\boldsymbol{\imath}$ trajectory and a certain fixed direction through the internal $u, v$ - coordinates:

$$
u=u, v=\int \frac{\sqrt{G}}{\sqrt{E}} \operatorname{ctg}(\alpha(u)) d u,
$$

which in the $O x y z$ Cartesian coordinate system will look like:

$$
\begin{gathered}
\boldsymbol{r}(\alpha(u))=\boldsymbol{R}\left[u, \int \frac{\sqrt{G}}{\sqrt{E}} \operatorname{ctg}(\alpha(u)) d u\right]= \\
\boldsymbol{r}\left[x\left(u, \int \frac{\sqrt{G}}{\sqrt{E}} \operatorname{ctg}(\alpha(u)) d u\right), y\left(u, \int \frac{\sqrt{G}}{\sqrt{E}} \operatorname{ctg}(\alpha(u)) d u\right), z\left(u, \int \frac{\sqrt{G}}{\sqrt{E}} \operatorname{ctg}(\alpha(u)) d u\right)\right] .
\end{gathered}
$$

Also, for the surface $\boldsymbol{R}(u, v)$ with orthogonal $u, v_{-}$coordinate lines (figure, b), the relation of the differentials $\sqrt{E} d u$ and $\sqrt{G} d v$ to the differential $d s$ д of the arc of the trajectory can be written by expressions:

$$
\frac{\sqrt{E} d u}{d s}=\sin (\alpha(u)) \frac{\sqrt{G} d v}{d s}=\cos (\alpha(u)),
$$

where does the trajectory $r(s)$ of a particle as a function of the independent variable $s$ (longitudinal parameter) in the internal $u, v_{-}$coordinates look like:

$$
u(s)=\int \frac{\sin (\alpha(u))}{\sqrt{E}} d s, v(s)=\int \frac{\cos (\alpha(u))}{\sqrt{G}} d s,
$$

or in the Oxyz Cartesian coordinate system:

$$
\begin{gathered}
r(s)=\boldsymbol{R}\left[\int \frac{\sin (\alpha(u))}{\sqrt{E}} d s, \int \frac{\cos (\alpha(u))}{\sqrt{G}} d s\right]= \\
\boldsymbol{r}\left[x\left(\int \frac{\sin (\alpha(u))}{\sqrt{E}} d s, \int \frac{\cos (\alpha(u))}{\sqrt{G}} d s\right), y\left(\int \frac{\sin (\alpha(u))}{\sqrt{E}} d s, \int \frac{\cos (\alpha(u))}{\sqrt{G}} d s\right), z\left(\int \frac{\sin (\alpha(u))}{\sqrt{E}} d s, \int \frac{\cos (\alpha(u))}{\sqrt{G}} d s\right)\right]
\end{gathered}
$$

Each of the above approaches to forming the trajectory $r$ of the particle in the inner $u, v_{-}$curvilinear coordinates of the surface $\boldsymbol{R}(u, v)$ has its own peculiarities by controlling its independent parameter $-t, u, v, \alpha, s$ (table). For example, the equation of the trajectory $\boldsymbol{r}(u)$ of a particle as a function of the independent parameter $u$, which determines the $v$ coordinate line of the surface with the particle on it, allows us to study its kinematic parameters on the bounded part $u=\left[u_{o}, u_{n}\right]$ and $v=\left[v_{o}, v_{n}\right]$ of the surface $\boldsymbol{R}(u, v)$, where $u_{o}, v_{o}$ - re the internal coordinates of the initial position of the particle on the surface. The formation of the trajectories $r(\alpha)$ as a function of the angle $\alpha(u)_{\text {м }}$ between the vector $\boldsymbol{\imath}$ of the tangent trajectory and the $v$-coordinate lines of the surface $\boldsymbol{R}(u, v)$ 
allows us to study the motion of the particle at the interval $\alpha=\left[\alpha_{o}, \alpha_{n}\right]$, where $\alpha_{o}$ is the initial angle of direction of the particle being thrown. For example, at $\alpha_{o}=0$ the particle begins to move along the $v$-coordinate line of the surface $R(u, v)$, а при $\alpha_{o}=\pi / 2$ - along the $u$-coordinate line of the surface..

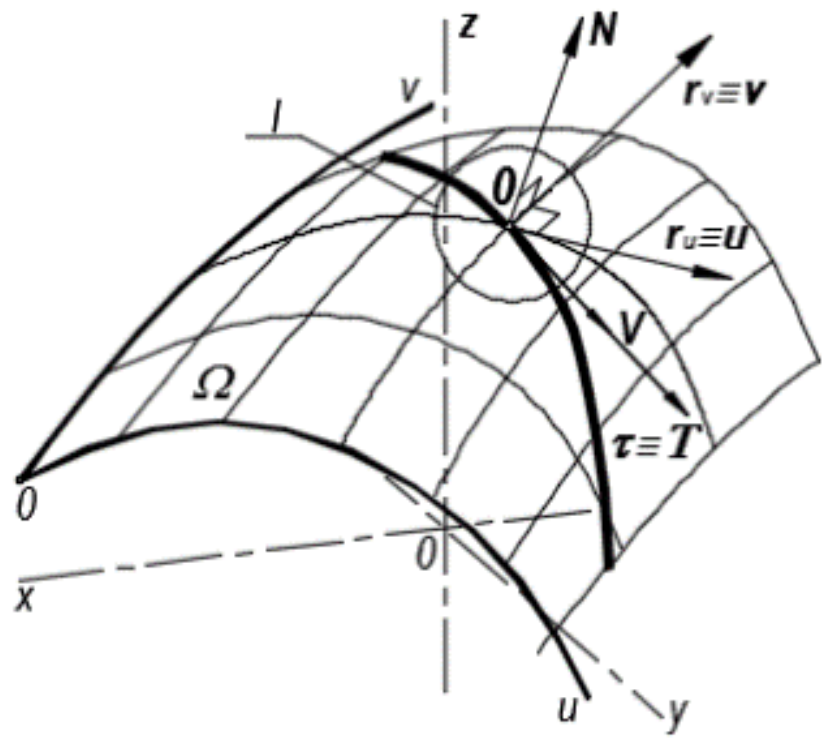

$a$

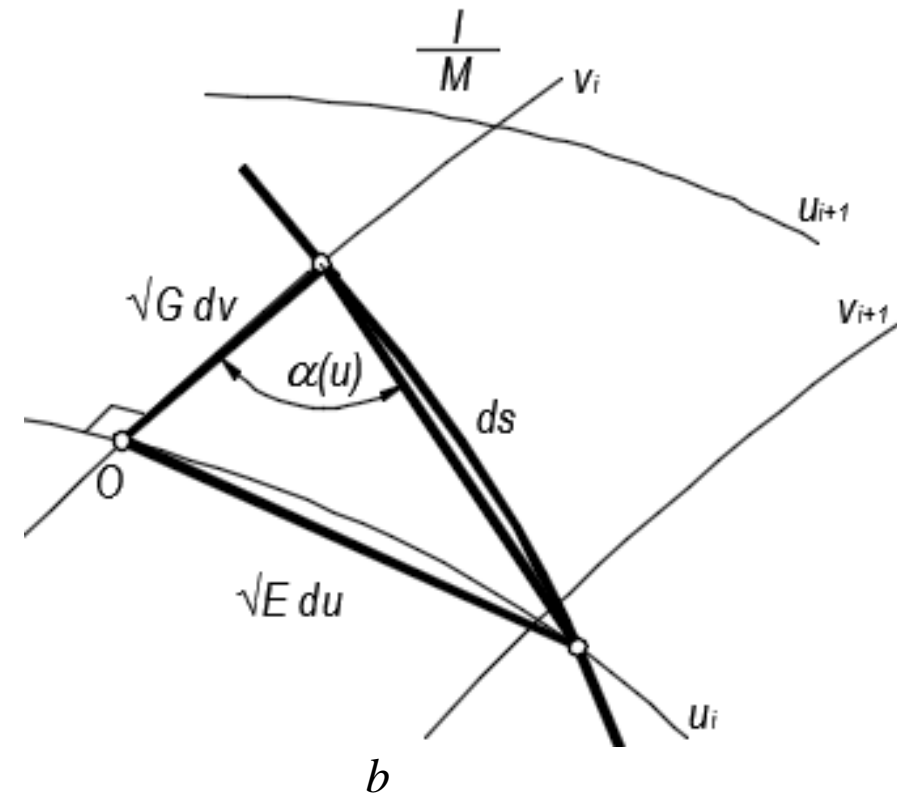

Figure. Specifying the trajectory of a particle in the internal coordinates of the surface:

$a$ - trajectory on the surface; $b$ - surface coordinate line differentials

The equations given in the table of the trajectories $\boldsymbol{r}(t), \boldsymbol{r}(u), \boldsymbol{r}(v), \boldsymbol{r}(\alpha)$ and $\boldsymbol{r}(s)$ in the inner $u, v$ coordinates of the surface $\boldsymbol{R}(u, v)$ re necessary and sufficient to determine $\mathrm{y}$ their general trajectory-kinematic characteristics, respectively, in the function of independent parameters $t, u, v, \alpha$ and $s$.

\section{Conclusions and Prospects.}

1. A method of computer simulation of particle motion on a rough surface is developed, which is based on the internal parameterization of the surface.

2. The computer-aided implementation of the particle motion simulation on a rough surface has been shown to be general and effective. 
1. The trajectories $r$ of the particle in the inner $u, v$. coordinates of the surface

\begin{tabular}{|c|c|c|}
\hline \multicolumn{3}{|c|}{$\boldsymbol{R}(u, v)$} \\
\hline Parameter & Internal coordinates & Trajectory \\
\hline time ${ }^{t}$ & $\begin{array}{l}u=u(t) \\
v=v(t)\end{array}$ & $\boldsymbol{r}(t)=\boldsymbol{R}[u(t), v(t)]$ \\
\hline position $u$ & $\begin{array}{c}u=u, \\
v=v(u)\end{array}$ & $\boldsymbol{r}(u)=\boldsymbol{R}[u, v(u)]$ \\
\hline position $v$ & $\begin{array}{c}u=u(v) \\
v=u\end{array}$ & $\boldsymbol{r}(v)=\boldsymbol{R}[u(v), v]$ \\
\hline $\begin{array}{l}\text { direction of } \\
\text { movement } \alpha\end{array}$ & $\begin{array}{c}u=u, \\
v=\int \frac{\sqrt{G}}{\sqrt{E}} \operatorname{ctg}(\alpha(u)) d u\end{array}$ & $\boldsymbol{r}(\alpha)=\boldsymbol{R}\left[u, \int \frac{\sqrt{G}}{\sqrt{E}} \operatorname{ctg}(\alpha(u)) d u\right]$ \\
\hline length $^{S}$ & $\begin{array}{l}u(s)=\int \frac{\sin (\alpha(u))}{\sqrt{E}} d s, \\
v(s)=\int \frac{\cos (\alpha(u))}{\sqrt{G}} d s\end{array}$ & $\boldsymbol{r}(s)=\boldsymbol{R}\left[\int \frac{\sin (\alpha(u))}{\sqrt{E}} d s, \int \frac{\cos (\alpha(u))}{\sqrt{G}} d s\right]$ \\
\hline
\end{tabular}

\section{Список літератури}

1. Адамчук В.В. Теория центробежных рабочих органов машин для внесения минеральных удобрений: монография / В.В. Адамчук. - К.: Аграрна наука, 2010. $178 \mathrm{c}$.

2. Аладьев В.3. Системы компьютерной алгебры: Maple: Искусство программирования / В.3. Аладьев. - Гродно: Лаборатория Базовых Знаний. - 2006. $792 \mathrm{c.}$

3. Несвідомін А.В. Моделювання руху частинки по шорсткій горизонтальній площині, яка здійснює прямолінійні коливальні переміщення / А.В. Несвідомін // Сучасні проблеми моделювання: зб. наук праць / МДПУ ім. Б. Хмельницького. Мелітополь: МДПУ, 2015. - Вип.4. - С.100-104.

\section{References}

1. Adamchuk, V. V. (2010). Teoriya tsentrobezhnykh rabochikh organov mashin dlya vneseniya mineral'nykh udobreniy: monografiya [Theory of centrifugal working bodies of machines for the application of mineral fertilizers]. Kyiv: Agrarna nauka, 178.

2. Alad'yev, V. Z., Boyko, V. K., Rovba, E. A. (2007). Programmirovaniye i razrabotka prilozheniy v Maple [Programming and application development in Maple]. Grodno-Tallin, 458.

3. Pylypaka, S. F., Nesvidomin, A. V. (2011). Avtomatyzatsiia modeliuvannia rukhu chastynky po hravitatsiinykh poverkhniakh na prykladi pokhyloi ploshchyny $\mathrm{v}$ 
"Енергетика і автоматика", №1, 2020 р.

systemi Maple [Automation of modeling of a particle motion on gravitational surfaces on an example of an inclined plane in the system Maple]. Prykl. heom. ta inzh. hraf. Kyiv: KNUBA, 86, 64-69.

\section{МОДЕЛЮВАННЯ ТРАЕКТОРІЇ РУХУ ЧАСТИНКИ НА ПОВЕРХНІ У ЇÏ ВНУТРІШНІХ КООРДИНАТАХ}

\section{А. В. Несвідомін}

Анотація. $\boldsymbol{y}$ багатьох технологічних процесах сільськогосподарського виробництва має місие взаємодія рухомої частинки з шорсткою поверхнею. Визначення закономірностей руху частинки по площині довільного положення в тривимірному просторі дозволяе виконати розрахунок конструктивнокінематичних параметрів робочих органів.

Компютерне моделювання руху частинки дозволяє замінити громіздкі аналітичні перетворення $i$ забезпечити діалоговий режим для проведення необхідних обчислювальних експериментів з аналізу руху частинки за різними вихідними умовами ї̈ кидання по будь-якій шорсткій поверхні, яка певним чином розташована в просторі.

Мета дослідження - моделювання траєкторії руху частинки на поверхні у ї внутрішніх координатах.

В основу загального алгоритму моделювання руху частинки по довільній поверхні покладено ї̈ внутрішню геометрію, яка виражається через коефіцієнти квадратичних форм, криві лінії на поверхні, супровідні тригранники.

У статті наведено формування траєкторії частинки на поверхні у ї̈ внутрішніх координатах.

Розглянуто різні підходи до формування траєкторії частинки $\boldsymbol{r}$ у внутрішніх $u$, v -криволінійних координатах поверхні $\boldsymbol{R}(u, v)$,які мають свої особливості за рахунок управління ї̈ незалежним параметром: час $t$, положення $u$, $v$, напрям руху $\alpha$, довжина $s$.

Наведені рівняння траєкторій $\boldsymbol{r}(t), \boldsymbol{r}(u), \boldsymbol{r}(v), \boldsymbol{r}(\alpha)$ i $\boldsymbol{r}(s)$ у внутрішніх $u, v$. координатах поверхні $\boldsymbol{R}(u, v)$ є необхідними $i$ достатніми для визначення $y$ загальному вигляді їх траєкторно-кінематичні характеристики відповідно $у$ функиії незалежних параметрів $t, u, v, \alpha i$.

Ключові слова: матеріальна точка, траєкторія руху, внутрішні координати

\section{МОДЕЛИРОВАНИЕ ТРАЕКТОРИИ ДВИЖЕНИЯ ЧАСТИЦЫ НА ПОВЕРХНОСТИ В ЕЕ ВНУТРЕННИХ КООРДИНАТАХ}

\section{А. В. Несвидомин}

Аннотация. Во многих технологических процессах сельскохозяйственного производства имеет место взаимодействие подвижной частицьь с иероховатой поверхностью. Определение закономерностей движения частицьы по плоскости 
"Енергетика і автоматика", №1, 2020 р.

произвольного положения в трехмерном пространстве позволяет выполнить расчет конструктивно-кинематических параметров рабочих органов.

Компьютерное моделирование движения частицы позволяет заменить громоздкие аналитические преобразования и обеспечить диалоговый режим для проведения необходимых вычислительных экспериментов по анализу движения частищьы с различныли исходными условиями ее бросания по любой мероховатой поверхности, определенным образом расположенной в пространстве.

Цель исследования - моделирование траектории движения частиць на поверхности в ее внутренних координатах.

В основу общего алгоритма моделирования движения частицьь по произвольной поверхности положена ее внутренняя геометрия, которая выражается через коэффициенть квадратичной формыл, кривьле линии на поверхности, сопроводительные трехгранники.

В статье приведено формирование траектории частицьы на поверхности в ее внутренних координатах.

Рассмотрены различные подходыл к формированию траектории частицьл $r$ во внутренних $u, v$-криволинейных координатах поверхности $R(u, v)$, которые имеют свои особенности за счет управления ее независимым параметром: время $t$, положение $u, v$, направление движения $\alpha$, длина $s$.

Приведенные уравнения траекторий $r(t), r(u), r(v), r(\alpha)$ u $r(s)$ во внутренних $u$, v-координатах поверхности $R(u, v)$ являются необходимыми и достаточными для определения в общем виде их траекторно-кинематических характеристик соответственно в функиии независимых параметров $t, u, v, \alpha u s$.

Ключевые слова: материальная точка, траектория движения, внутренние координать 